\title{
Rynek tantalu na początku XXI wieku
}

\author{
Mariusz Krzak $^{1}$, Andrzej Gałaś ${ }^{2}$, Katarzyna Król $^{1}$
}

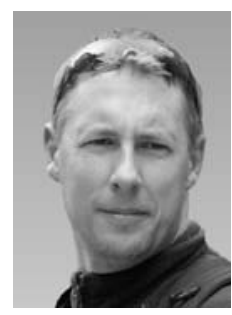

M. Krzak

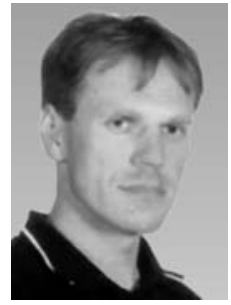

A. Gałaś

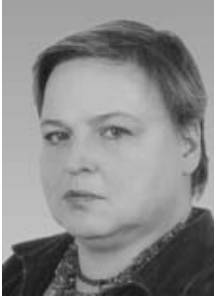

K. Król

Tantalum market at the beginning of the $21^{\text {st }}$ century. Prz. Geol., 69: 234-243; doi: $10.7306 / 2021.13$

A b s tract. Tantalum, despite the low consumption level, is one of the strategically important metals for the world economy. In terms of the world production volume, it places oneself on a distant position; however, its price was one of the highest at the beginning of the $21^{\text {st }}$ century. Tantalum is a transition metal with a high melting point and high chemical resistance, which determines the spectrum of its applications. It is used mainly in the capacitors production, sputtering and as an additive for superalloys. The $21^{\text {st }}$ century is a period of noticeable changes in the structure of quantitative supplies, consumption centres and price fluctuation. There are numerous but small centres of primary production (artisanal mines) in Africa. Sources of tantalum raw-materials (mineral deposits and its reserves), basic factors determining the economic situation on the market, substitution possibilities and the prices evolution are presented and assessed in the paper. Marginal significance of the economy of tantalum raw materials for Poland is mentioned.

Keywords: tantalum market, primary and secondary production, consumption, prices, trade, substitution

Tantal (Ta) to metal należący do grupy wanadowców (V, Nb, Ta). Został wydzielony i opisany w 1802 r. przez szwedzkiego chemika Andersa Gustafa Ekeberga (jakkolwiek wyizolowany metal zawierał znaczną domieszkę niobu). Przemysłową produkcję rozpoczęto zaś w latach 20. XX w., po upowszechnieniu metod rozdziału niobu i tantalu. Nazwa metalu pochodzi od postaci z greckiej mitologii - Tantala. Najważniejszym minerałem i pierwotnym źródłem tantalu jest tantalit $(\mathrm{Fe}, \mathrm{Mn}) \mathrm{Ta}_{2} \mathrm{O}_{6}$. W połowie lat 30. XX w. przemysł stalowniczy wykorzystywał rocznie 20-30 t koncentratów tantalu (Bolewski, 1994). Jednym ze złóż najwcześniej zagospodarowanych w celu pozyskania tego metalu jest złoże pegmatytów Greenbushes w Australii, eksploatowane od 1888 r. W 1970 r. światowa produkcja tantalu nieznacznie przekraczała 550 t koncentratu, osiaggając maksima rzędu 700 t na przełomie lat 70 i 80 XX w.

Nierówny poziom produkcji tantalu w II połowie XX w. był powodowany kilkoma czynnikami: małymi zasobami odkrytych złóż, zmienną jakością rud, atrakcyjnością (rozwój nowych technologii) i dostępnością gospodarczą surowca. Liderzy światowej produkcji zmieniali się z biegiem lat. W latach 70. XX w. prym wiodły Kanada i kraje byłego Związku Socjalistycznych Republik Radzieckich (ZSRR), w latach 80. XX w. dołączyła Australia i Brazylia, w dalszej kolejności Chiny. W XXI w. nastąpiło istotne, w ujęciu geograficznym, przeniesienie ośrodków pierwotnej produkcji do Afryki (Demokratyczna Republika Konga - DRK, Rwanda, Nigeria). Mocną pozycję utrzymała nadal Brazylia. Zmalało wyraźnie znaczenie Kanady, Australii i państw byłego bloku sowieckiego.

Od 1974 r. analiz rynku tantalu oraz informacji o stabilności łańcucha dostaw dostarcza organizacja zrzeszająca producentów i konsumentów tantalu i niobu (Tantalum-Niobum International Study Centre - TIC). Do organizacji nie przystapił ZSRR, a później, po odzyskaniu państwowości, nie przyłączyły się Ukraina i Kazachstan. Wykorzystanie tantalu w przemyśle zbrojeniowym po- wodowało, że dane o produkcji górniczej Związku Radzieckiego nie były ujawniane. W obecnych statystykach, np. amerykańskiej służby geologicznej (USGS), wielkość produkcji w Rosji pojawia się dopiero od roku 2020 r., natomiast w republikach postsowieckich (Kazachstan, Ukraina) dane te nie są dostępne, chociaż jest bardzo prawdopodobne, że odbywa się tam wytwórczość tantalu rzędu kilkudziesięciu ton rocznie (Szlugaj, Smakowski, 2015). Produkcja tantalu jest obecnie prowadzona w około 20 krajach, w porównaniu do ok. 30-40 zaraz po II wojnie światowej.

Tantal jest twardym, kowalnym, stalowoszarym metalem, odpornym na korozję oraz działanie większości kwasów i zasad. Ma bardzo wysoką temperaturę topnienia i cechuje się wysoką biokompatybilnością. O znaczeniu gospodarczym tantalu decyduje w głównej mierze koniunktura przemysłu elektronicznego, gdzie jest wykorzystywany do produkcji kondensatorów elektrolitycznych. Wspomniana odporność chemiczna predestynuje tantal do wykorzystywania w produkcji aparatury chemicznej (wymienniki ciepła, rury, zawory i zbiorniki na kwasy). Tantal jest stosowany jako dodatek stopowy do specjalnych gatunków stali nierdzewnej i kwasoodpornej. Jako składnik nadstopów zapewnia im wytrzymałość i stabilność faz. Stopy tantalu są stosowane w branżach: lotniczej i astronautycznej (wykładziny wnętrz komór spalania silników statków kosmicznych i samolotów), elektronicznej i medycznej (narzędzia chirurgiczne i dentystyczne). Tantal dobrze poddaje się obróbce i spawaniu. Wytwarza się z niego także wyroby zegarmistrzowskie i jubilerskie. Węglik tantalu $(\mathrm{TaC})$ jest bardzo twardy i jest składnikiem węglików spiekanych, tlenek tantalu $\left(\mathrm{Ta}_{2} \mathrm{O}_{5}\right)$ jest składnikiem szkieł optycznych oraz warstw elektroluminescencyjnych. Tantal i jego związki są wykorzystywane w technologii materiałów mikroelektronicznych - np. półprzewodnikowe warstwy amorficzne $\mathrm{Cu}_{20} \mathrm{Ta}_{80}$, diody półprzewodnikowe Ta-Si-GaAs (Skrzypek, 2012).

\footnotetext{
${ }^{1}$ Akademia Górniczo-Hutnicza w Krakowie, al. Mickiewicza 30, 30-059 Kraków; krzak@agh.edu.pl; kkrol@geol.agh.edu.pl

${ }^{2}$ Instytut Gospodarki Surowcami Mineralnymi i Energią PAN, ul. Wybickiego 7A, 31-261 Kraków; agalas@min-pan.krakow.pl
} 
W ocenie Komisji Europejskiej (EC, 2020) tantal jest zaliczany do grupy surowców krytycznych. Cechuje go średnie znaczenie gospodarcze wśród surowców objętych tą listą i jednocześnie niskie ryzyko zaopatrzenia (ryc. 1). Według brytyjskiej służby geologicznej (BGS) względne ryzyko stabilności dostaw jest kwalifikowane jako średnie - w dziesięciostopniowej skali wynosi ono 7,1 pkt (BGS, 2015).

\section{RUDY, ZLOŻA I ŚWIATOWE ZASOBY TANTALU}

Tantal jest pierwiastkiem rozproszonym w skorupie ziemskiej i nie występuje w przyrodzie w stanie wolnym. Udziały wagowe tantalu, według różnych autorów, wynoszą od 0,74 do 5,7 ppm (Rudnick, Sally, 2003), a jego klark jest przyjmowany na poziomie 0,7 ppm (Rudnick, Sally, 2003; BGS, 2011). Podwyższona zawartość jest odnotowywana w skałach alkalicznych i karbonatytach. W procesach hipergenicznych minerały tantalu są odporne na wietrzenie i tworzą niekiedy wtórne złoża o znaczeniu gospodarczym.

Większość minerałów pełniących funkcję nośników tantalu to tlenki - znane są również krzemiany, jednak ich wystapienia są bardzo nieliczne. Tantalowi towarzyszy zwykle niob, a szereg kolumbit $(\mathrm{Fe}, \mathrm{Mn})(\mathrm{Nb}, \mathrm{Ta})_{2} \mathrm{O}_{6}$ tantalit $(\mathrm{Fe}, \mathrm{Mn})(\mathrm{Ta}, \mathrm{Nb})_{2} \mathrm{O}_{6}$ jest najpowszechniej występującą fazą mineralną $\mathrm{Nb}$ i Ta o najważniejszym znaczeniu przemysłowym i potocznie jest nazywany coltanem.
Wodginit ( $\mathrm{Ta}, \mathrm{Nb}, \mathrm{Sn}, \mathrm{Mn}, \mathrm{Fe}) \mathrm{O}_{2}$ jest kolejnym istotnym źródłem odzysku tantalu. Minerały z grupy pirochloru $(\mathrm{Na}, \mathrm{Ca})_{2} \mathrm{Nb}_{2} \mathrm{O}_{6}(\mathrm{O}, \mathrm{OH}, \mathrm{F})$, jakkolwiek wzbogacone zwykle w tantal (mikrolit), dostarczaja przede wszystkim niobu, a jako źródło tantalu są traktowane podrzędnie.

Złoża rud tantalu o znaczeniu gospodarczym są nieliczne, rozmieszczone w kilkunastu krajach świata (ryc. 2) i najczęściej są związane ze skałami magmowymi (granity, pegmatyty, sjenity i karbonatyty). Znane są ponadto złoża wtórne, powstałe wskutek wietrzenia złóż pierwotnych i późniejszych procesów osadowych.

Tantal tworzy niekiedy samodzielne złoża rud, jednak częściej jest kopaliną towarzyszącą rudom innych metali (głównie $\mathrm{Sn}, \mathrm{Li}, \mathrm{Nb}$ ). Rudy mają zwykle skład kompleksowy: Nb-Ta lub Li-Cs-Be-Ta-(Sn) i występują w trzech typach złóż (BGS, 2011):

1) karbonatytowych,

2) alkalicznych i peralkalicznych granitach i sjenitach,

3) granitach i pegmatytach typu LCT (lit-cez-cynalithium-caesium-tantalum).

Osobno są wyróżniane złoża okruchowe, które są związane ze zwietrzeliną wymienionych pierwotnych typów złóż. Są z nich pozyskiwane koncentraty tantalitowe, tantalitowo-niobowe i inne tantalonośne.

Złoża karbonatytów występują zwykle w formie stromych pni, dajek lub kopulastych intruzji. Składają się głównie (ponad 50\%) z kalcytu i dolomitu. Ich zonalną budowę podkreślają żyły różnorodnych, często bardzo

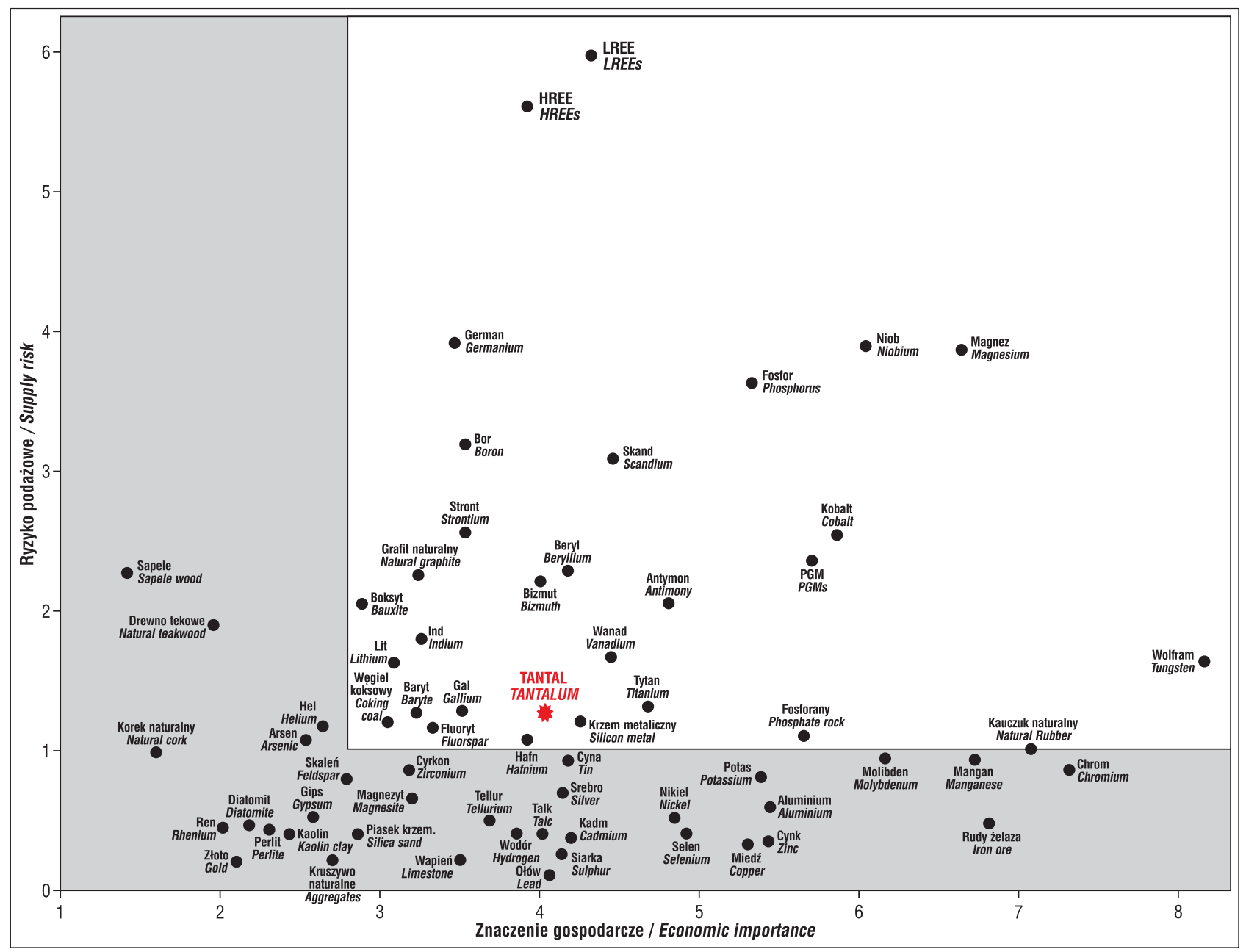

Ryc. 1. Tantal na tle surowców krytycznych dla gospodarki UE (EC, 2020)

Fig. 1. Tantalum on a background of critical raw materials for the EU economy (EC, 2020) 


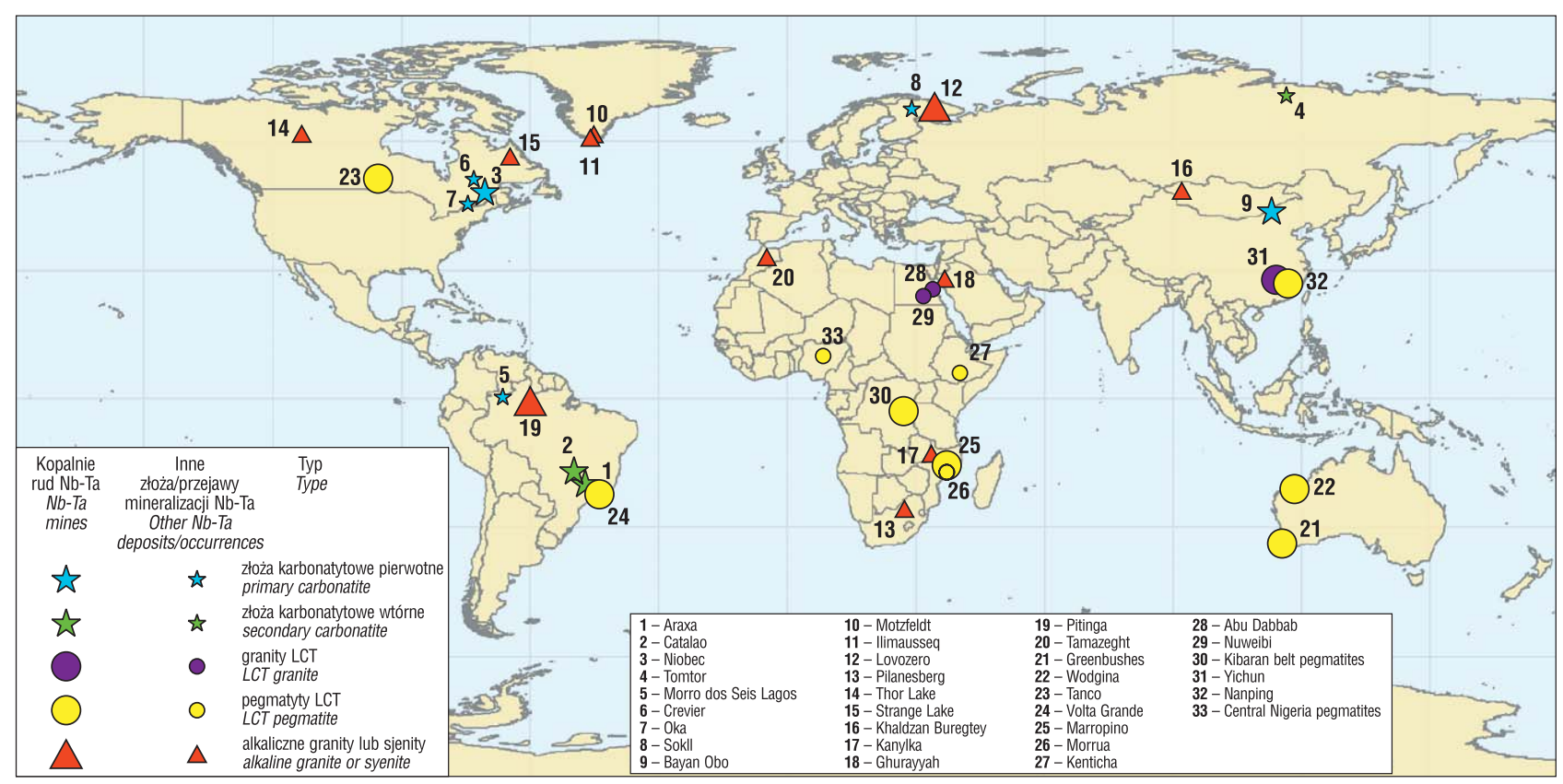

Ryc. 2. Rozmieszczenie kopalń i głównych typów złóż rud Nb-Ta (BGS, 2011)

Fig. 2. Distribution of major Nb-Ta mines and deposits - by deposit type (BGS 2011)

rzadkich minerałów. Często występują w sąsiedztwie intruzji sjenitów nefelinowych oraz rzadziej kimberlitów, piroksenitów i perydotytów. Karbonatyty stanowią najważniejszy typ złóż pierwiastków ziem rzadkich (REE). Typowe przykłady to: Niobec, Oka, Blue River, Crevier i Upper Fir w Kanadzie; Araxá, Catalão I i II, Morro dos Seis Lagos w Brazylii; Mount Weld w Australii i Bayan-Obo w Chinach (Paulo, Strzelska-Smakowska, 1993; Orris, Grauch, 2002; BGS, 2011; Fan i in., 2016; Schulz i in., 2017).

Złoża alkalicznych granitów i sjenitów (albitytowe) są zwykle związane ze strefami ryftów i zapadlisk na platformach, za łukiem magmowym orogenów. Mogą to być samodzielne małe intruzje alkaliczne lub te części wielkich masywów magmowych, które charakteryzują się znaczną alkalicznością. Złoża tego typu wykazują znaczną zmienność mineralizacji, a tym samym zawartości składnika użytecznego. Są to złoża REE z dużą zawartością cyrkonu, itru, niobu, tytanu, berylu, toru i uranu. Typowym przykładem jest złoże Thor Lake i Strange Lake w Kanadzie. W kompleksie intruzywnym Blachford Lake (granity i sjenity) występuje formacja alkaliczna Nechalacho - nefelinowy sjenit silnie okruszcowany Be, Y, REE, Nb i Ta. Nośnikiem Ta jest kolumbit i tantalit. Inne obiekty, w których nośnikiem tantalu jest łoparyt w agpaitowych sjenitach nefelinowych, to Kanyika (Malawi), Ghurayyah (Arabia Saudyjska), Łowozero (Rosja), Motzfeld i Ilimaussaq (Grenlandia) Pitinga (Brazylia), Pilanesberg (Republika Południowej Afryki), Yichun (Chiny) oraz Bikita (Zimbabwe) (Paulo, Strzelska-Smakowska, 1993; Orris, Grauch, 2002; BGS, 2011; Schulz i in., 2017).

Złoża granitów i pegmatytów LCT powstaja jako końcowe fazy procesów magmowych lub też metamorficznych, wskutek działania roztworów hydrotermalnych, zwykle obficie zmineralizowanych i bogatych w cynę. Najczęściej są to pegmatyty z dobrze wykrystalizowanym kasyterytem. Towarzyszą im koncentracje: Ta, Nb oraz W, $\mathrm{Li}, \mathrm{Be}$ i Cs. Koncentracje Ta odkryto dotychczas tylko w pegmatytach archaiku i proterozoiku. Przykładem jest złoże Greenbushes w Australii, uznane za największy na świecie kompleks pegmatytowy. Początkowo wydobywano zwie- trzelinę pegmatytów, a obecnie w kopalni podziemnej eksploatuje się pegmatyty. Pozostałe złoża tego typu to: Wodgina i Bald Hill (Australia), Volte Grande i Mibra (Brazylia), Kenticha (Etiopia), Marropino (Mozambik), Abu Dabbab i Nuweibi (Egipt), Yichun (Chiny) i Tanco (Kanada) (Paulo, Strzelska-Smakowska, 1993; Orris, Grauch, 2002; BGS, 2011; Schulz i in., 2017).

Wyróżniane w niektórych klasyfikacjach złoża okruchowe obejmują strefy wietrzeniowe, zwykle ponad pierwotnymi wystąpieniami karbonatytów, granitów i pegmatytów z okruszcowaniem Nb-Ta lub sekwencje osadowe w bezpośrednim sąsiedztwie intruzji. Są one typowe dla krajów tropikalnych (środkowa Afryka, Australia, Brazylia). Wychodnie pierwotnych skał przykrywa zwykle zwietrzelina kaolinowo-illitowa z luźnymi ziarnami tantalitu, kolumbitu, U-mikrolitu, kasyterytu i scheelitu. Zawartość Ta sięga 15-100 g/m³ (Paulo, Strzelska-Smakowska, 1993). Złoża okruchowe występują w promieniu nieprzekraczającym $1 \mathrm{~km}$ od wychodni skał pierwotnych, a więc typowa dla złóż okruchowych redepozycja składników użytecznych nie ma w tym wypadku miejsca lub jest obserwowana na mała skalę. Przykładowe złoża to: Araxá i Catalão (Brazylia), Tomtor (Rosja), Greenbushes (Australia) i Lueske (DRK).

Większość złóż Ta o znaczeniu gospodarczym, w porównaniu do złóż innych metali, to małe obiekty geologiczne (ryc. 3). Przeważają złoża zawierające od 1 do $100 \mathrm{mln}$ ton rudy $\mathrm{Ta}_{2} \mathrm{O}_{5}$. Całkowita wielkość zasobów to zwykle kilkaset mln ton rudy o relatywnie niskiej zawartości wagowej metalu.

Światowe zasoby Ta o znaczeniu gospodarczym, według ocen USGS (tab. 1), wynoszą ponad 140 tys. ton (Callaghan, 2021), podczas gdy zasoby geologiczne są szacowane na ok. 300 tys. ton, zatem zakładając obecny poziom wydobycia zapewniają niemal 100-letnią wystarczalność. Trzeba nadmienić, że dostępne statystki światowych zasobów tantalu pozostają znacznie zróżnicowane. Bardziej precyzyjne, choć nadal nie zawsze do końca wiarygodne, są dane o zasobach pojedynczych, zagospodarowanych górniczo złóż lub projektów geologiczno-górniczych 
przewidzianych do rychłego zagospodarowania, szczególnie w Australii, Brazylii czy Kanadzie.

Produkcja górnicza jest prowadzona w kilku obszarach, z rosnącym sumarycznie natężeniem, podczas gdy w latach 2000-2020 baza zasobowa kopalin tantalu została dokładniej rozpoznana i uległa istotnemu powiększeniu, a jej ocena jest zmienna w czasie i dynamiczna, uzależniona od koniunktury rynkowej (głównie cen $\mathrm{Sn}, \mathrm{Li}$ i Nb). Największym zapleczem podażowym dysponują Brazylia i Australia. Kraje te raportują posiadanie niemal 100\% światowych zasobów Ta - uwzględnianych w statystykach USGS. Znaczące zasoby posiadają niewątpliwie Chiny, DRK, Etiopia, Mozambik, Rwanda i Rosja. Część łatwo dostępnych zasobów znajduje się w niestabilnych gospodarczo i politycznie krajach środkowej Afryki. Brak danych o zasobach tych krajów jest powodowany niedoborem wykwalifikowanej administracji geologicznej (Simandl i in., 2018).

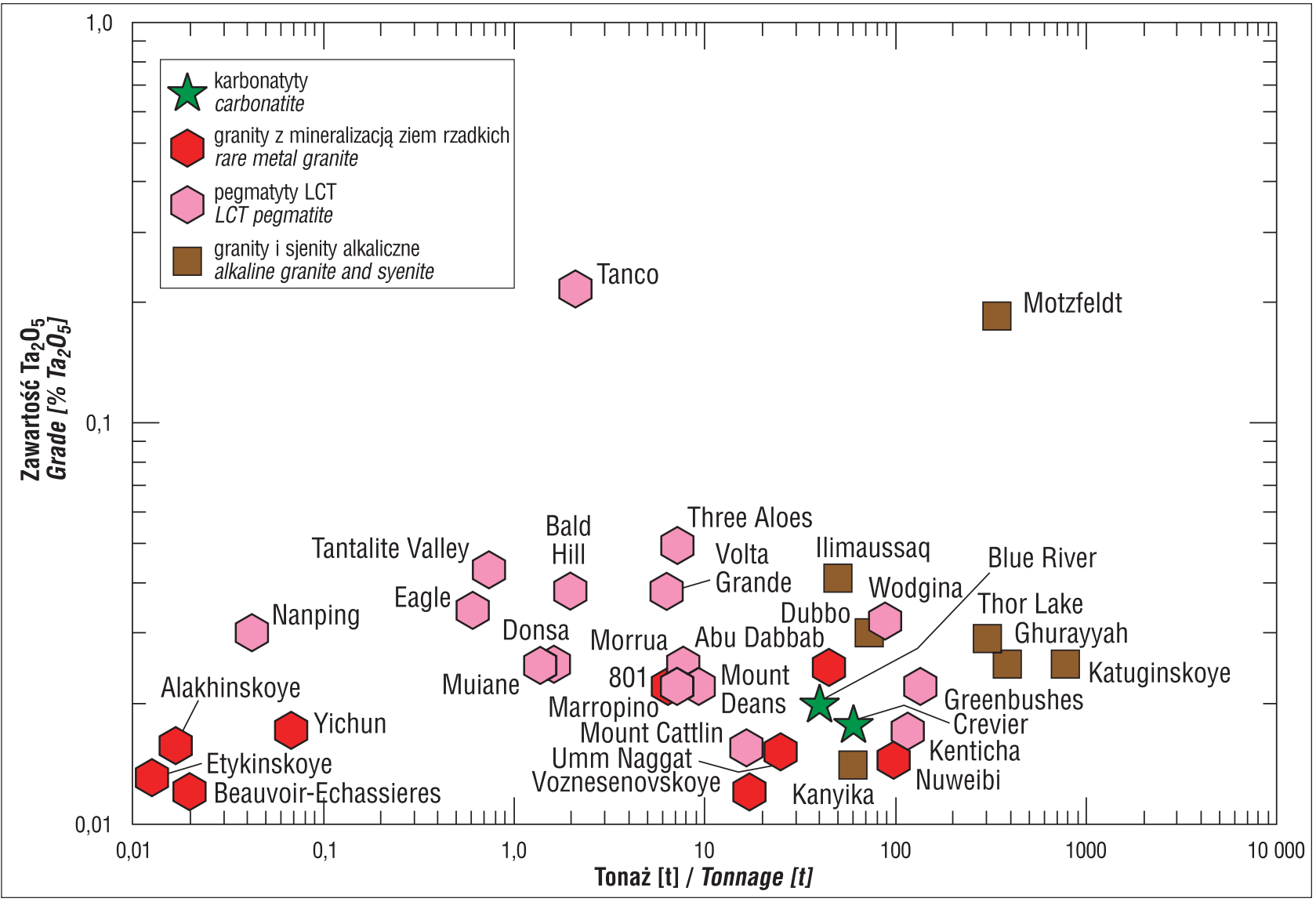

Ryc. 3. Relacja jakości do tonażu głównych złóż tantalu z podziałem na typy genetyczne (Schulz i in., 2017)

Fig. 3. Grade versus tonnage of major tantalum deposits in the world, by deposit type or source, in million metric tonnes (Schulz et al., 2017)

Tab. 1. Zmiany światowej bazy zasobowej tantalu (tony) w latach 2000-2020 (Cunningham, 2001; Magyar, 2006; Papp, 2011, 2016; Padilla, 2020; Callaghan, 2021)

Table 1. Changes of global tantalum resource base (tonnes) in the years 2000-2020 (Cunningham, 2001; Magyar, 2006; Papp, 2011, 2016; Padilla, 2020; Callaghan, 2021)

\begin{tabular}{|c|c|c|c|c|c|c|c|c|}
\hline \multirow{3}{*}{$\begin{array}{l}\text { Australia } \\
\text { Australia } \\
\end{array}$} & \multicolumn{2}{|c|}{2000} & \multicolumn{2}{|c|}{2005} & 2010 & 2015 & 2019 & 2020 \\
\hline & \multirow{2}{*}{\begin{tabular}{|c|}
$\begin{array}{c}\text { Zasoby } \\
\text { przemyslowe } \\
\text { Reserves }\end{array}$ \\
25000 \\
\end{tabular}} & \multirow{2}{*}{$\begin{array}{c}\begin{array}{c}\text { Zasoby } \\
\text { geologiczne } \\
\text { Resources }\end{array} \\
45000\end{array}$} & \multirow{2}{*}{$\begin{array}{c}\begin{array}{c}\text { Zasoby } \\
\text { przemyslowe } \\
\text { Reserves }\end{array} \\
40000\end{array}$} & \multirow{2}{*}{$\begin{array}{c}\begin{array}{c}\text { Zasoby } \\
\text { geologiczne } \\
\text { Resources }\end{array} \\
80000\end{array}$} & \multicolumn{4}{|c|}{$\begin{array}{l}\text { Zasoby przemyslowe } \\
\text { Reserves }\end{array}$} \\
\hline & & & & & 40000 & 67000 & $\begin{array}{c}55000 \\
15000 \text { (JORC) } \\
\end{array}$ & $\begin{array}{c}99000 \\
44000 \text { (JORC) } \\
\end{array}$ \\
\hline $\begin{array}{l}\text { Brazylia } \\
\text { Brazil }\end{array}$ & ND & 3000 & ND & ND & 65000 & 36000 & 34000 & 40000 \\
\hline $\begin{array}{l}\text { Kanada } \\
\text { Canada }\end{array}$ & 3000 & 5000 & 3000 & ND & ND & ND & ND & ND \\
\hline $\begin{array}{l}\text { Nigeria } \\
\text { Nigeria }\end{array}$ & ND & 7000 & ND & ND & ND & ND & ND & ND \\
\hline $\begin{array}{l}\text { Mozambik } \\
\text { Mozambique }\end{array}$ & ND & ND & ND & ND & 3200 & ND & ND & ND \\
\hline $\begin{array}{l}\text { Świat } \\
\text { World }\end{array}$ & 28000 & 60000 & 43000 & 150000 & $>100000$ & $>100000$ & $>90000$ & $>140000$ \\
\hline
\end{tabular}

ND - dane niedostępne / data not available 
Schulz i in. (2017), identyfikując geologiczny potencjał zasobowy tantalu, wskazują na Brazylię jako dominującego potentata, gdzie jest ulokowanych około $40 \%$ światowych zasobów. Pozostałe udziały mają Australia (20\%), Chiny i południowa Azja (11\%), Rosja i środkowy wschód (10\%), środkowa Afryka (9\%), pozostała Afryka (7\%), północna Ameryka (2\%) i Europa (1\%). Złoża w Brazylii są związane głównie z rozległymi kompleksami karbonatytowymi bądź pegmatytami, podczas gdy w Australii są to przeważnie pegmatyty LCT. Stany Zjednoczone wykazują około 55 tys. ton tantalu w złożach udokumentowanych, których eksploatacja jest jednak uznawana za nieopłacalną wobec cen z 2020 r. (Callaghan, 2021).

W Polsce nie są znane złoża tantalu i brak jest perspektyw na odkrycie obiektów o znaczeniu gospodarczym.

\section{PRODUKCJA PIERWOTNA I DOSTAWY}

Tantal jest najczęściej kopaliną towarzyszącą rudom innych metali (głównie $\mathrm{Sn}, \mathrm{Li}, \mathrm{Nb}$ ), w związku z tym wahania cen i popytu tych metali moga powodować zmiany dynamiki jego wydobycia i opłacalności pozyskiwania. Produkcja pierwotna tantalu jest prowadzona w stosunkowo nielicznych krajach (tab. 2).

Dominującym źródłem dostaw jest wydobycie z licznych, lecz małych, rzemieślniczych kopalń (artisanal and small scale mining - ASM). Niewielkie, ale łatwo dostępne złoża zagospodarowano w krajach Afryki: Nigerii, DRK, Zimbabwe, Rwandzie czy Namibii (Melcher i in, 2008). Roskill (2020) szacuje udział tej produkcji na nieco ponad $50 \% \mathrm{w}$ skali świata, pozostałe wolumeny zapewnia produkcja ze złóż tantalowych (33\%) i pozyskanie tantalu jako produktu ubocznego z kopalń innych kopalin metalicznych, głównie litu (14\%). Przewidywana jest zmiana tej struktury w ciagu najbliższych 5-10 lat, w wyniku której udział ASM ulegnie pomniejszeniu do około $1 / 3$ strumienia dostaw, a zwiększy się wkład produkcji z pozostałych źródeł, głównie na skutek wzrostu produkcji litu i rosnącego zapotrzebowania na ten surowiec przemysłu motoryzacyjnego.

Światowa produkcja pierwotna tantalu w dwóch dekadach XXI w. to naprzemienne okresy wzrostów i spadków. Maksima produkcji przekraczające $1500 \mathrm{t}$ odnotowano w latach 2002 i 2004, rekordowe wielkości powyżej 1800 t w 2018 r. (ryc. 4).

Główni producenci tantalu zmieniali się $\mathrm{z}$ biegiem lat, niektórzy z nich niekiedy zupełnie wygaszali działalność. Od końca lat 80. XX w. umacniała się pozycja Australii, która aż do 2009 r. była najważniejszym producentem tantalu i jego koncentratów. W 2001 r., jak i niemal w całej pierwszej dekadzie XXI w., z Australii i Brazylii pochodziło $90 \%$ podaży (ryc. 5 ).

Tab. 2. Produkcja górnicza Ta w latach 2000-2020 (Cunningham, 2001; Magyar, 2006; Papp, 2011, 2016; Padilla, 2020, Callaghan, 2021)

Table 2. Mine tantalum production in the years 2000-2020 (Cunningham, 2001; Magyar, 2006; Papp, 2011, 2016; Padilla, 2020; Callaghan, 2021)

\begin{tabular}{|c|c|c|c|c|c|c|c|}
\hline & & & & & & & \\
\hline & 2000 & 2010 & 2015 & 2019 & $\begin{array}{c}\text { Wydobycie [t] } \\
\text { Output }[\mathrm{t}]\end{array}$ & $\begin{array}{l}\text { Udzial [\%] } \\
\text { Share [\%] }\end{array}$ & $\begin{array}{c}\text { Relacja } 2020 / 2000[\%] \\
\text { Proportion 2020/2000 [\%] }\end{array}$ \\
\hline $\begin{array}{l}\text { Australia } \\
\text { Australia }\end{array}$ & 485 & ND & ND & 67 & 30 & 1,7 & 6 \\
\hline $\begin{array}{l}\text { Brazylia } \\
\text { Brazil }\end{array}$ & 90 & 180 & 115 & 430 & 370 & 21,5 & 411 \\
\hline $\begin{array}{l}\text { Kanada } \\
\text { Canada }\end{array}$ & 57 & ND & - & - & - & - & - \\
\hline $\begin{array}{l}\text { Kongo (Kinshasa) } \\
\text { Congo (Kinshasa) }\end{array}$ & 130 & ND & 350 & 580 & 670 & 39 & 515 \\
\hline $\begin{array}{l}\text { Rwanda } \\
\text { Rwanda }\end{array}$ & - & 110 & 410 & 336 & 270 & 15,7 & - \\
\hline $\begin{array}{l}\text { Etiopia } \\
\text { Ethiopia }\end{array}$ & 38 & ND & ND & 70 & 60 & 3,5 & 158 \\
\hline $\begin{array}{l}\text { Mozambik } \\
\text { Mozambique }\end{array}$ & - & 120 & ND & ND & ND & - & - \\
\hline $\begin{array}{l}\text { Burundi } \\
\text { Burundi }\end{array}$ & - & - & - & 38 & 30 & 1,7 & - \\
\hline $\begin{array}{l}\text { Nigeria } \\
\text { Nigeria }\end{array}$ & 4 & ND & ND & 180 & 160 & 9,3 & 4000 \\
\hline $\begin{array}{l}\text { Rosja } \\
\text { Russia }\end{array}$ & ND & ND & ND & 26 & 26 & 1,5 & - \\
\hline $\begin{array}{l}\text { Chiny } \\
\text { China }\end{array}$ & - & ND & 60 & 76 & 70 & 4,1 & - \\
\hline $\begin{array}{l}\text { Inne kraje } \\
\text { Other countries }\end{array}$ & 122 & $271^{\mathrm{a}}$ & 165 & 47 & 35 & 2 & 29 \\
\hline $\begin{array}{l}\text { Świat } \\
\text { World }\end{array}$ & 836 & 681 & 1100 & 1850 & 1720 & 100 & 206 \\
\hline
\end{tabular}

Objaśnienia: e - dane szacunkowe; a - obejmuje następujące kraje: Burundi, Kongo (Kinshasa), Etiopia, Somalia, Uganda, Zimbabwe; ND - dane niedostęne

Eksplanations: e-estimated data; a - includes the following countries: Burundi, Congo (Kinshasa), Ethiopia, Somalia, Uganda, Zimbabwe; ND - data not available 


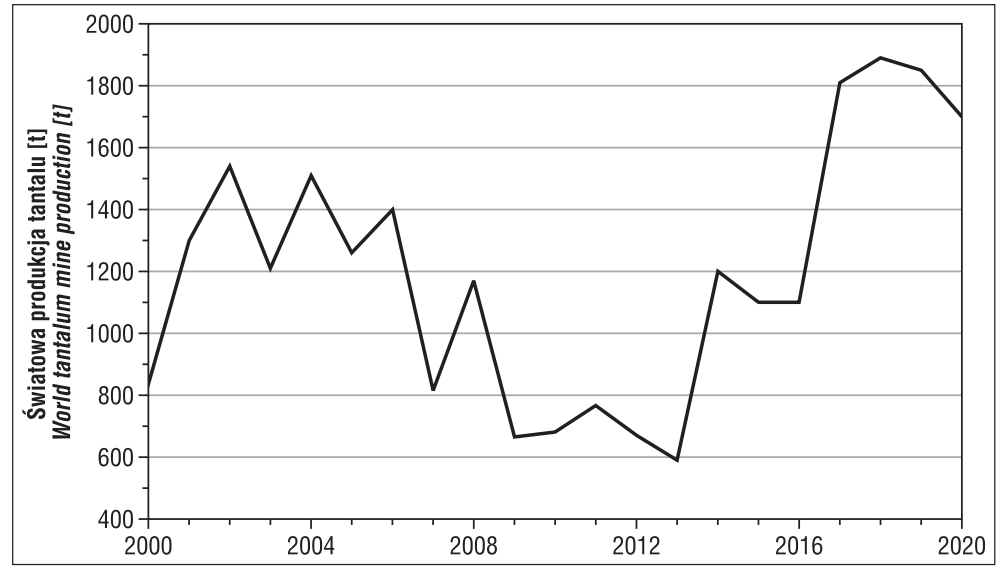

Ryc. 4. Światowa produkcja tantalu w latach 2000-2020 (na podstawie danych USGS, tony zawartego metalu)

Fig. 4. World tantalum mine production in the years 2000-2020 (based on USGS data, data in tonnes of metal content)

Zanik produkcji w Kanadzie zbiegł się z odkryciem i zagospodarowaniem złóż w Tajlandii. Prace techniczne (remonty, udostępnienie nowych partii złóż) w dwóch najważniejszych kopalniach w Australii (należących do Talison Minerals - obecnie Global Advanced Metals): Greenbushes (rudy Sn, Li) i Wodgina (rudy Fe, Li) spowodowały, że w latach 2007-2012 produkcja tantalu w Kanadzie całkowicie wygasła. Miejsce lidera dostaw początkowo zajęła Brazylia, gdzie rozpoczęto wydobycie w złożach: Barreiro (Cia, Brasiliera de Metalurgia e Mineração), Catalão (Anglo American Brazil Ltd.) oraz Volta Grande (CIF Mineração). Przypuszcza się, że wzrost znaczenia producentów ze środkowej Afryki był spowodowany recesją na rynku metali w 2008 r. i spadkiem cen koncentratów $\mathrm{Ta}_{2} \mathrm{O}_{5}$. To spowodowało wygaszanie produkcji w Australii, Kanadzie, ale także w Mozambiku i Etiopii (ryc. 5). W rezultacie po zużyciu zapasów nastapił wzrost cen i możliwość wejścia na rynek producentów, którzy dysponowali łatwo dostępnymi zasobami rudy (DRK, Rwanda, Burundi). Jednocześnie (2009/2010) zmniejszyło się światowe zapotrzebowanie na kondensatory, których produkcja jeszcze w 2007 r. zużywała $60 \%$ Ta. Spadek ten był spowodowany ograniczeniem produkcji komputerów na rzecz zwiększenia dostaw tabletów, które nie wymagają kondensatorów. W efekcie znacznie zredukowano wydobycie Ta w Kanadzie, która aż do 2010 r. była liczącym się konkurentem. W latach 2010-2014 największym producentem koncentratów tantalu okazała się Rwanda (31\% produkcji światowej) i DRK (19\%), a Brazylia zajmowała trzecie miejsce (14\%). Trzeba zaznaczyć, że liczne kopalnie w Afryce (Etiopia - Kenticha Mine, Nigeria, Mozambik Noventa Ltd.) były oceniane jako ryzykowne w ujęciu dostaw ze względu na archaiczne metody eksploatacji i niestabilną sytuację polityczną. Eksploatacja jest tam często prowadzona przez małe podmioty, bez koncesji i uregulowanego statusu. Całkowita podaż z państw afrykańskich stanowi prawie $65 \%$ światowej podaży pierwotnej i pochodzi prawie wyłącznie z ASM. Na ten sposób eksploatacji przychylnym okiem patrzą lokalne władze państwowe, bo w wielu przypadkach zapewnia on pozyskanie środków do życia i spokój społeczny (Wołkowicz, 2013). Istnieją obszary, gdzie produkcja jest kontrolowana przez lokalne grupy bojowników, którzy wykorzystują miejscową ludność do niewolniczej pracy. Mimo to w latach 2010-2014 aż 95\% dostaw tantalu dla Unii Europejskiej pochodziło z Afryki, a od 2009 r.

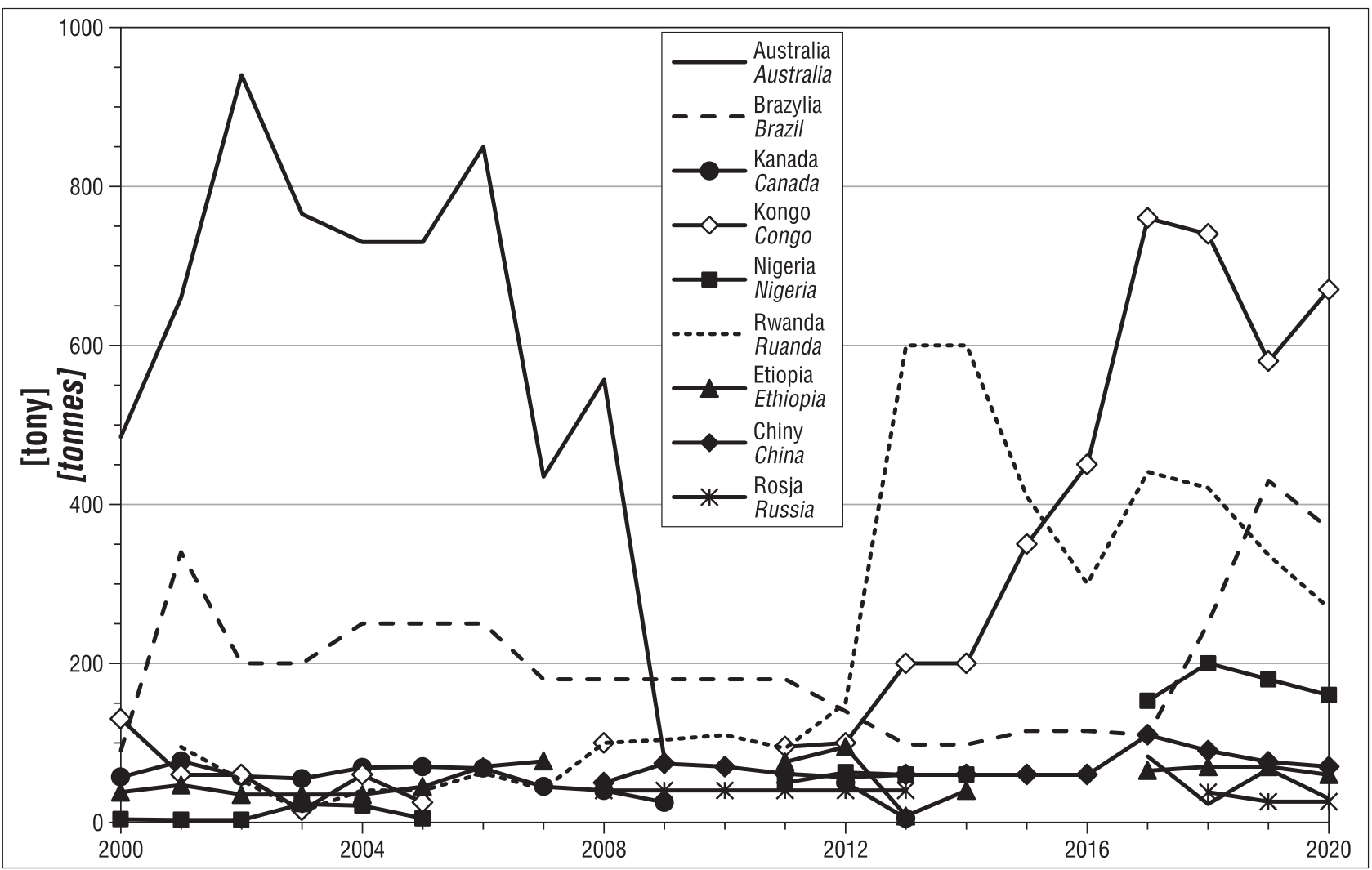

Ryc. 5. Najwięksi producenci tantalu w latach 2000-2020 (na podstawie danych USGS, tony zawartego metalu)

Fig. 5. The largest tantalum mine producers (based on USGS data, data in tonnes of tantalum content) 
więcej niż 50\% światowej produkcji pochodzi z tego kontynentu. Bardzo prawdopodobne jest, że wysoka pozycja na rynku producentów z subsaharyjskiej Afryki wynika z prowadzenia rabunkowej gospodarki, często wiąże się ze stosowaniem terroru wobec pracowników, choć sygnałami zmian są np. działania Ministerstwa Zasobów Rwandy, gdzie od 2016 r. jest prowadzony monitoring kopalń i nadzór nad pochodzeniem pierwotnych surowców tantalu. Pomimo zmian kraje skupione wokół regionu Wielkich Jezior Afrykańskich nadal są uważane za ryzykownych partnerów handlowych. Biorąc pod uwagę jako miarę koncentracji rynku indeks Herfindahla-Hirschmana (HHI), rynek dostaw tantalu wydaje się być umiarkowanie lub nawet silnie skoncentrowany (DERA, 2018).

$\mathrm{Na}$ początku 2019 r. obserwowano wzrost podaży niskokosztowych koncentratów tantalowych jako produktów ubocznych. Za trend ten odpowiadały dwie kopalnie litu w Australii Zachodniej, jednak w sierpniu tego roku tendencja została odwrócona. Bald Hill Mine ograniczała operacje wydobywcze, a projekt Pilgangoora, zakładający niemal dwukrotne zwiększenie zdolności produkcyjnych litu i tantalu, został odroczony w czasie. Jednocześnie brak zgody Ministerstwa Środowiska Estonii uniemożliwił odzyskiwanie niobu i tantalu w operacjach NPM Silmet $A S$, ponieważ firma ta osiaggnęła limit tonażowy przechowywania radioaktywnych odpadów poflotacyjnych (Padilla, 2020). W 2020 r. na skutek czasowego zamknięcia (z powodu COVID-19) kopalń w Brazylii i Rwandzie ogólnoświatowa produkcja tantalu była niższa (Callaghan, 2021).

Nieco bardziej złożony obraz produkcji górniczej dostarczały statystyki TIC (TIC, 2020, 2021). Według tych danych w 2019 r. nastąpił spadek produkcji górniczej aż o $26,5 \%$ w porównaniu do 2018 r., a od rekordowego 2014 r. o ponad $60 \%$. Odnotowano zmniejszenie dostaw z kopalń tantalu, a jeszcze bardziej znaczący spadek zaobserwowano $\mathrm{w}$ przypadku produkcji tantalu $\mathrm{w}$ formie produktu ubocznego. Wzrosło jedynie nieznacznie pozyskanie tego metalu z żużli cynowych. Ujęcie to odbiega od statystyk USGS (Callaghan, 2021) i zapewne jest powodowane niepełnymi danymi statystycznymi, wynikającymi z wycofania się z członkostwa w TIC dużej grupy producentów górniczych.

\section{PRODUKCJA WTÓRNA, OBROTY}

Równocześnie ze wzrostem zainteresowania stosowaniem tantalu do celów przemysłowych stale zwiększa się na rynku udział tego metalu pozyskiwanego $\mathrm{z}$ recyklingu. W 1994 r. było to 8\%, w 2010 - 20\% i 2017 - 21\% (Paulo, Strzelska-Smakowska, 1993; Szlugaj, Smakowski, 2015; TIC, 2018). Trudno przewidzieć, czy nastąpi dalszy rozwój odzyskiwania Ta, gdyż główny surowiec - kondensatory nie łatwo poddaje się recyklingowi (Simandl i in., 2018). Powoduje to, że nie ma zorganizowanego recyklingu tantalu, wykorzystującego zużyte produkty zawierające ten metal, jak również perspektyw jego rozwoju (DERA, 2018).

W Polsce tantal odzyskiwano z surowców wtórnych w zakładach CEMAT ' 70 Centrum Naukowo-Produkcyjnego Materiałów Elektronicznych S.A. w Skawinie. Obecny, większościowy udziałowiec spółki nie prowadzi odzysku tantalu.

Podstawowymi surowcami tantalu w obrocie międzynarodowym są koncentraty zawierające minimum 30\% $\mathrm{Ta}_{2} \mathrm{O}_{5}$, jakkolwiek koncentraty o niższej jakości (min. 20\% $\mathrm{Ta}_{2} \mathrm{O}_{5}$ ) również znajdują nabywców. Cena koncentratu jest zwykle pochodną samej zawartości $\mathrm{Ta}_{2} \mathrm{O}_{5}$ - ewentualne domieszki $\mathrm{Nb}_{2} \mathrm{O}_{5}$ przeważnie są ignorowane. O możliwości zbytu koncentratów decyduje ponadto zawartość pierwiastków promieniotwórczych. Zanieczyszczenia torem i uranem dyskwalifikują je jako surowiec z obrotu handlowego (TIC, 2021). Oprócz koncentratów przedmiotem obrotu są proszki tlenku tantalu o czystości 99,5 lub 99,99\% oraz tantal metaliczny o czystości 99,9\%, 99,95\% i 99,99\%, dostarczany zwykle w formule EXW lub FOB. Największe dostawy pochodzą z Brazylii i krajów afrykańskich, podczas gdy najbardziej chłonne rynki to kraje wysoko rozwinięte, np. Japonia, USA, Niemcy i Wielka Brytania.

Poziom importu surowców tantalu do Polski waha się od setek kg do nieco ponad 2 t. Dostawy obejmują tantal nieobrobiony (w tym proszki i złom) oraz wyroby z tantalu (sztaby, pręty, kształtowniki, drut, blachy, taśmy i folie), pochodzące głównie z Niemiec i Austrii, a także z Chin i USA. Systematycznie notowany był również reeksport odpadów, złomu i wyrobów z tantalu, przeważnie do Niemiec, Wielkiej Brytanii i Rosji. Saldo jakościowe obrotów surowcami tantalu miało zwykle ujemną wartość, jakkolwiek przy dużym udziale reeksportu uzyskiwano dodatni bilans, np. w latach 2010 i 2013 (Szlugaj, Smakowski, 2015).

\section{ZASTOSOWANIE, ZUŻYCIE I SUBSTYTUTY}

Początkowo tantal był uznawany za uszlachetniacz stali. Po II wojnie światowej nastapiła istotna zmiana zastosowań. Jest używany przeważnie w postaci metalicznej, wlewek, proszku, stopów z W, Co, Fe i Ni oraz związków chemicznych (tlenki, węglik - temperatura topnienia ponad $3000^{\circ} \mathrm{C}$, sole i in.). Największy wpływ na wielkość produkcji tantalu miał i nadal ma rozwój elektroniki, technologii budowy statków kosmicznych, reaktorów jądrowych oraz stali narzędziowych. W latach 90. XX w. tantal znalazł szerokie zastosowanie w produkcji kondensatorów. Rozwój technologii pozwolił wykorzystać właściwości tego metalu do magazynowania energii. Do 2010 r. ponad połowę Ta zużywano do produkcji kondensatorów. Obecnie obserwuje się spadek zainteresowania tą gałęzią przemysłu. Już w 2011 r. do produkcji kondensatorów zużywano tylko ok. ${ }^{1} / 3$ całości wytworzonego Ta. W metalurgii stopów w różnych gałęziach przemysłu zwiększa się natomiast udział proszków tantalu (ryc. 6).

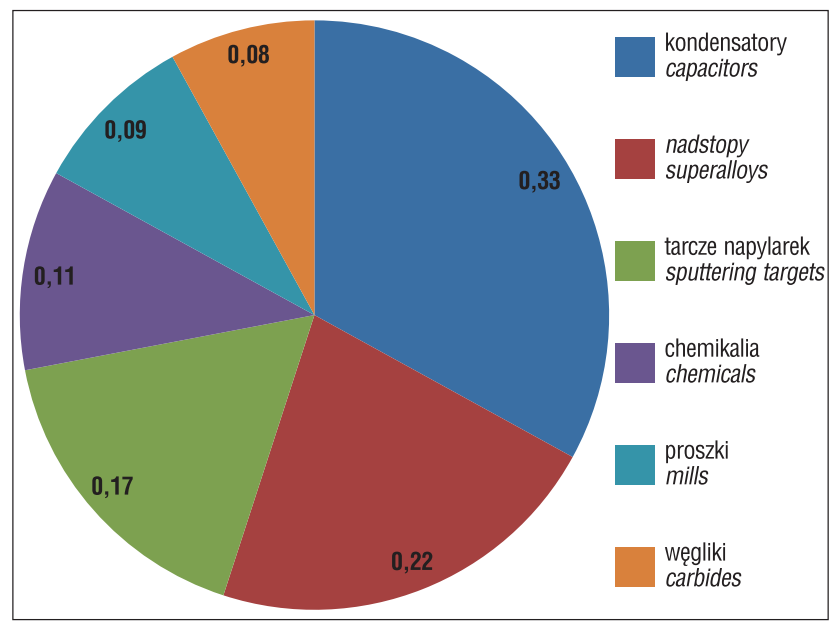

Ryc. 6. Globalne zużycie końcowe surowców tantalu w latach 2010-2014 (Stratton, 2013)

Fig. 6. Global end-use of tantalum in the period 2010-2014 (Stratton, 2013) 


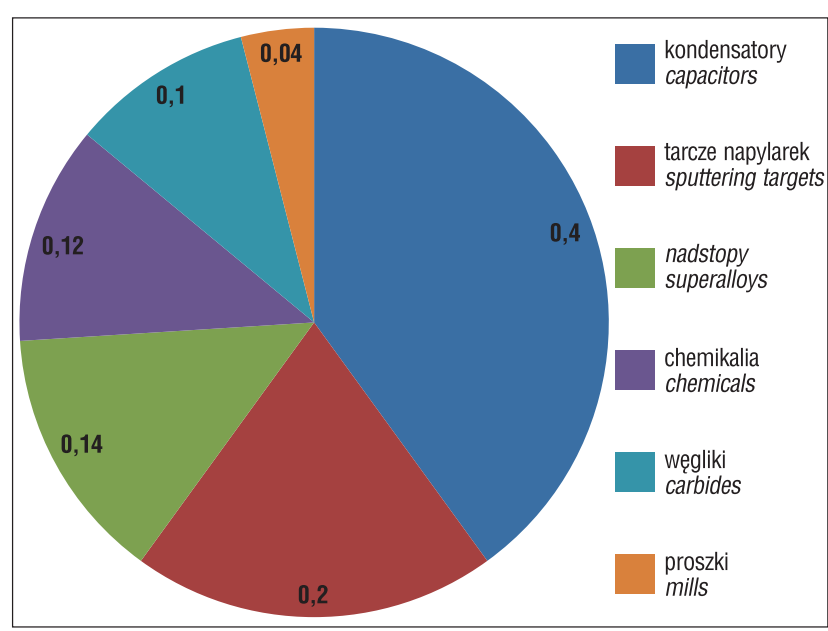

Ryc. 7. Struktura zużycia końcowego surowców tantalu w krajach UE (EC, 2020)

Fig. 7. Structure of tantalum end-use in the EU countries (EC, 2020)

Tantal jest używany do nadawania wytrzymałości i odporności na wysokie temperatury superstopom stosowanym w przemyśle lotniczym i energetyce. W przemyśle chemicznym jest wykorzystywany jako wykładzina rur, zbiorników i naczyń. Względna łatwość obróbki i wysoka biokompatybilność tantalu pozwala na zastosowanie go w medycynie $-z$ jego udziałem są wykonywane np. stenty do podtrzymywania naczyń krwionośnych, płytki, zamienniki kości oraz medyczne spinacze i druty. Tlenek tantalu jest przydatny $\mathrm{w}$ optyce, ponieważ służy do zwiększenia współczynnika załamania światła przez soczewkę, a z węglika tantalu są wykonywane końcówki narzędzi skrawających (TIC, 2018).

Najszerszym polem zastosowań tantalu w UE, podobnie jak na świecie (ryc. 7), jest produkcja kondensatorów. W UE większość tantalu wykorzystywanego do wyrobu kondensatorów pochodzi $\mathrm{z}$ importu, a nie $\mathrm{z}$ własnego wydobycia. Drugim ważnym zastosowaniem jest produkcja tarcz do napylania, które są wykorzystywane do osadzania powłok w celu zabezpieczenia, modyfikacji lub uszlachetnienia oryginalnej powierzchni. Ze względu na znaczenie sektora lotniczego ważnym zastosowaniem tantalu w UE są również superstopy. Nadstopy znajdują zastosowanie w produkcji silników odrzutowych, a także lądowych turbin gazowych (EC, 2020).

Udział UE w imporcie surowców Ta jest trudny do oszacowania, wg EC $(2017,2020)$ mieści się zazwyczaj w granicach 50-100 t rocznie. Należy jednak zwrócić uwagę, że UE importuje 500-600 t kondensatorów zawierających Ta. Wykorzystuje też około połowę tantalu zużywanego do produkcji specjalnych stopów stosowanych w przemyśle lotniczym i rakietowym.

Właściwości tantalu są tak unikalne, że wszelkie substytuty zwykle powodują obniżenie jakości produktu, zwiększenie jego gabarytów, masy lub parametrów użytkowych. Można stwierdzić, że najbliższym substytutem jest niob. Niob także jest stosowany do produkcji kondensatorów, ale znacznie skraca czas ich pracy. Podobne właściwości stopów stali specjalnych można uzyskać, dodając Mo, V, Ni i Co, ale są one droższe. W produkcji materiałów ogniotrwałych tantal jest zastępowany przez $\mathrm{Hf}$, Ir, Mo, Nb i W. W produkcji kondensatorów jest wypierany przez kondensatory ceramiczne i na bazie aluminium (Polyak, 2018; Padilla, 2020).

\section{CENY}

Rynki mniej pospolitych w obrocie metali są zwykle dość nieprzejrzyste, a zmienność cen jest najczęściej pochodną rzeczywistego popytu na surowce i możliwości podaży, a nie wynikiem np. spekulacji, choć te bywają też motorem wahań. Dla cen tantalu nie bez znaczenia jest fakt, że większość dostaw pochodzi z krajów obarczonych dużym ryzykiem gospodarczym i politycznym. Przedmiotem obrotu jest najczęściej koncentrat, rzadziej proszek lub metal. Indeksowanie cen koncentratów, najpowszechniejszych surowców obrotu handlowego, bywa kłopotliwe $\mathrm{z}$ racji zróżnicowania i zmiennej zawartości $\mathrm{Ta}_{2} \mathrm{O}_{5}$. Transakcje surowcami tantalu są zwykle umowne, a ceny i wielkości obrotu nie są zazwyczaj ujawniane.

Starsze analizy cen surowców tantalu, dotyczące okresu 1960-1990, wskazują, że rynek tantalu był wyjątkowo niespokojny, podatny na zakupy spekulacyjne, często wynikające $\mathrm{z}$ niepewności dostaw. Współcześnie sytuacja jest bardziej stabilna, jakkolwiek nie wypracowano jednolitych sposobów notowań, a kwotowanie dostaw odbywa się na drodze negocjacji i kontraktów bilateralnych. W dekadach 1960-1990 cena $1 \mathrm{~kg}$ koncentratu $\mathrm{Ta}_{2} \mathrm{O}_{5}$ mieściła się w przedziale 20-50 USD. Wyjątkiem były lata 1979-1981, kiedy cena ta osiągnęła niemal $300 \mathrm{USD} / \mathrm{kg}$. Dekada 2000-2010 (ryc. 8) rozpoczęła się gwałtowną przeceną na rynku tantalu i gwałtownym spadkiem popytu na tantal, który nastąpił po dwuletnim okresie eskalacji cen napędzanych popytem przez przemysł elektroniczny. Później ceny utrzymywały się w granicach 50-70 USD $/ \mathrm{kg}$. W $2011 \mathrm{r}$. cena koncentratów tantalitu i czystego metalu gwałtownie wzrosła - odpowiednio do 280000 i $336000 \mathrm{USD} / \mathrm{t}$ (ryc. 8,9 ) -i pozostała na tak wysokim poziomie przez trzy lata w wyniku powolnego ożywienia gospodarki światowej, wyczerpywania się zapasów, a także wprowadzenia zapisów dotyczących pochodzenia surowców mineralnych (ustawa Dodda-Franka). Zakłócenia po stronie podaży tradycyjnie miały największy wpływ na trendy cen koncentratów

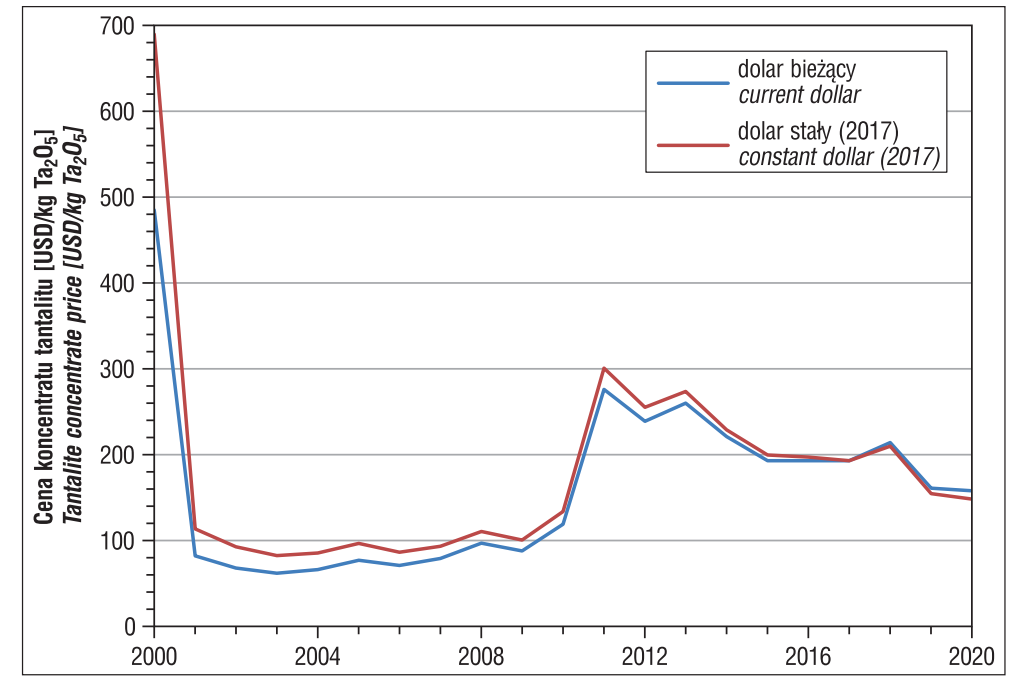

Ryc. 8. Ceny koncentratów tantalitu ( $\min .30 \% \mathrm{Ta}_{2} \mathrm{O}_{5}$ ) w latach $2000-2020$ (wg danych USGS, 2013; Papp, 2016; Padilla, 2020)

Fig. 8. Tantalite concentrate prices (min. $30 \% \mathrm{Ta}_{2} \mathrm{O}_{5}$ ) in the years $2000-2020$ (based on USGS, 2013; Papp, 2016; Padilla, 2020 data) 


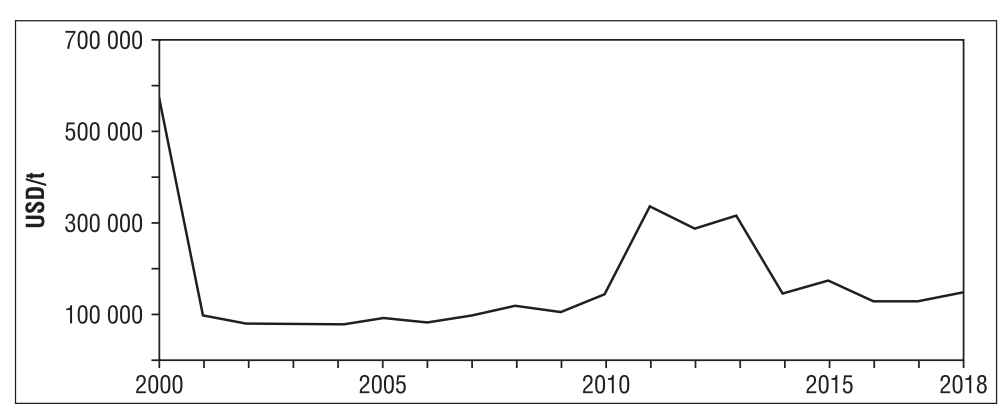

Ryc. 9. Cena tantalu metalicznego (http://www.metalary.com/tantalum-price/) Fig. 9. Unit tantalum price (US\$/tonne; http://www.metalary.com/tantalum-price/)

w ostatnich latach. Zwiększenie dostępności taniego, ubocznie pozyskiwanego tantalu $\mathrm{z}$ wydobycia rud litu spowodowało znaczny spadek cen w latach 2013-2018 (ryc. 8, 9). W latach 2019-2020 średnia cena tantalitu spadła o około $26 \%$, co nadal było związane z rosnącą podażą tantalu z rud litowych.

\section{PROGNOZY RYNKU I PODSUMOWANIE}

Rynek tantalu jest stosunkowo wąski, biorąc pod uwagę rozproszenie producentów i użytkowników, tym samym jest podatny na szybkie zmiany wolumenów dostaw i cen. Same wahania cen tantalu oraz zmiany technologii w przemyśle elektronicznym powodują, że duże, kosztowne projekty górnicze są wstrzymywane. Rozwijają się natomiast projekty poszukiwawcze dotyczące pozyskiwania innych metali, gdzie obecność tantalu jest rozpatrywana dopiero na etapie projektu górniczego jako możliwy do odzysku produkt uboczny. Od 2011 r. tantal znajduje się na liście surowców krytycznych USA, także Unia Europejska uważa go za pierwiastek krytyczny.

Od 1990 r. główne zużycie tantalu dotyczyło produkcji kondensatorów. Szczególne właściwości tantalu powodują, że kondensatory wytworzone $\mathrm{z}$ jego dodatkiem są wyjątkowo stabilne, odporne na uszkodzenia i zapewniają dużą wydajność wolumetryczną i gęstość mocy. Są to parametry wykorzystywane w dużych jednostkach obliczeniowych, komputerach przemysłowych, serwerach itp. Obecnie stosowane ceramiczne kondensatory MLCC klasy II lepiej spełniają wymagania miniaturyzacji i możliwości produkcji na dużą skalę w celu obsługi smartfonów i innych urządzeń przenośnych. Dlatego znaczna część rynku kondensatorów została zajęta lub zostanie wyparta przez kondensatory ceramiczne. Może to oznaczać spadek zapotrzebowania na tantal. Generalizując, w najbliższej przyszłości należy zwrócić uwagę na następujące czynniki decydujące o fluktuacjach na rynku tantalu:

$\square$ popyt na lit (prognozowany jest wzrost zapotrzebowania do produkcji pojazdów elektrycznych i hybrydowych, a intensyfikacja produkcji litu spowoduje zapewne zwiększenie dostaw taniego tantalu);

$\square$ ograniczenia $\mathrm{w}$ produkcji kondensatorów tantalowych (zastępowanie przez ceramiczne);

$\square$ zbyt wolne zmiany strukturalne i lokalne konflikty zbrojne w państwach Afryki subsaharyjskiej.

Konflikty militarne w Afryce dwukrotnie przybierały na sile, pierwszy raz pod koniec XX w., a następnie na przełomie wieków. Największe walki i zgrupowania wojsk (w tym armii rządowych) koncentrują się w Demokratycznej Republice Konga. Strefy kontrolowane przez organizacje militarne powstają także w krajach sąsiadujących z DRK. Pod płaszczem haseł wyzwolenia oddziały te kontroluja wydobycie surowców, które zapewnia im przychody wystarczające na zakup broni i kontynuację walk (Bleischwitz i in., 2012). W 2001 r. ONZ zwróciła uwagę, że rozwój technologiczny na świecie odbywa się kosztem zniewolenia rzeszy ludzi w Afryce (w tym kobiet i dzieci), zmuszanych do ciężkiej, niewolniczej pracy. Wstrzymano dostawy Ta i innych surowców z DRK do Europy i USA. W efekcie na rynku pojawiła się produkcja z innych krajów Afryki: Rwandy, Zimbabwe i Mozambiku. Był to częściowo efekt przerzucania produktu, aby ukryć prawdziwe źródło jego pochodzenia. Przyjęta w USA w 2010 r. ustawa o reformie i ochronie konsumentów Dodda-Franka (sekcja 1502), wymuszająca konieczność ujawniania źródeł pochodzenia dostaw, między innymi tantalu, ograniczyła nieco proceder wyzysku. Od 2016 r. tantal (jako coltan - ruda Ta-Nb) znajduje się na liście metali European Partnership for Responsible Minerals (EPRM), których produkcja jest związana $\mathrm{z}$ łamaniem praw człowieka. W 2019 r. EPRM rozpoczęło projekt na rzecz poprawy socjalnej sytuacji górników wydobywających tantal ze złóż w DRK i Ugandzie. Niestety, pozostałe kraje wydają się być poza obszarem działania EPRM ze względu na brak stabilności politycznej i bezpieczeństwa.

W Unii Europejskiej górnicza produkcja tantalu nie jest prowadzona, chociaż w zachodniej i środkowo-wschodniej części tego kontynentu są zlokalizowane jedne $\mathrm{z}$ najbogatszych stref występowania mineralizacji wolframowo-cynowo-(tantalowo-litowej). W latach 1961-1985 przeprowadzono kilka wstępnych projektów wydobywczych w granitach Penouta w północnej Hiszpanii (González i in., 2017). Leukogranit Penouta był intensywnie eksploatowany w latach 70 . XX w. w celu uzyskania głównie surowców cyny, a koncentraty kolumbitu-tantalitu były produktem ubocznym. Wydobycie i metody przeróbki nie były jednak wydajne, a ceny rynkowe niskie, co doprowadziło do rezygnacji z tych projektów. W stawach osadowych nagromadzono jednak duże ilości odpadów, potencjalnych nośników mineralizacji tantalowej. Obecnie Strategic Minerals Spain wykorzystuje stare stawy osadowe i składowiska (ok. $12 \mathrm{Mt}$ odpadów o średniej zawartości 428 ppm Sn i 35 ppm Ta), koncentrując się głównie na dwóch obiektach: Balsa Grande (4,8 Mt, 387 ppm Sn i 48 ppm Ta) oraz Balsa Pequena (0,22 Mt, 421 ppm Sn i 42 ppm Ta). Rozważane jest ponowne otwarcie kopalni (Alfonso i in., 2020). Wstępne poszukiwania i analizy dotyczące obiektów z mineralizacją litu i towarzyszącym tantalem są prowadzone w Austrii (projekt Wolfsberg), Niemczech (Sadisdorf), Czechach (Cinovec) oraz Portugalii (Sepeda, Alvarroes, Mina de Barroso) (TIC, 2019). Spośród wymienionych najbardziej zaawansowany jest projekt Wolfsberg, gdzie rozpoczęcie produkcji litu (i prawdopodobnie tantalu) jest prognozowane na 2023 r. (https://europeanlithium.com). Potencjalnych złóż tantalu o znaczeniu przemysłowym można oczekiwać w Finlandii, Francji, Norwegii, Szwecji i na Grenlandii. Znaczne ilości Ta zostały wyprodukowane w krajach byłego Związku Radzieckiego (Rosji czy Ukrainie). Produkcja utrzymywała się na poziomie 120-160 ton (Bolewski, 1994), jakkolwiek brak jest wiarygodnych danych. W najnowszych statystykach USGS ponownie ukazuje się Rosja (tab. 2).

Roskill (2020) oczekuje, że ożywienie gospodarki po zakłóceniach spowodowanych pandemią COVID-19 doprowadzi do gwałtownego wzrostu popytu na tantal w 2021 r. Prognozuje ponadto powrót do optymistycznych 


\section{$\rightarrow$}

Ryc. 10. Prognoza zaopatrzenia w surowce tantalu w perspektywie roku 2026 (DERA, 2018)

Fig. 10. Tantalum raw materials supply forecast by 2026 (DERA, 2018)

wskaźników wzrostu w długim okresie, szczególnie w sektorach, w których tantal nie ma oczywistych i tanich substytutów. Silny wzrost popytu na tantal będzie wspierany przez rosnące wskaźniki elektryfikacji, zwłaszcza w sektorze motoryzacyjnym, co będzie napędzać wzrost głównego zastosowania końcowego - kondensatorów, a także związków chemicznych tantalu i tarcz napylających. Technologia sieci mobilnej piątej generacji $(5 \mathrm{G})$ będzie również stawiać większe wymagania elektronice. Oczekuje się, że rozprzestrzenianie się COVID-19 będzie miało negatywny wpływ na produkcję silników lotniczych, podczas gdy w dłuższej perspektywie odejście od paliw kopalnych może zaszkodzić sektorowi, zwłaszcza popytowi na nadstopy $\mathrm{w}$ przemysłowych turbinach gazowych (IGT). Niemiecka Agencja Zasobów Mineralnych (DERA, 2018) przewiduje w krótkim czasie dwa scenariusze podaży tantalu na rynku w kontekście dodatkowej produkcji z istniejących kopalń i nowych projektów, a także dostaw z recyklingu i pozyskania z żużli cyny (ryc. 10).

Artykuł powstał przy wsparciu EIT RawMaterials (projekt iTARG3T) oraz subwencji badawczej AGH.

\section{LITERATURA}

ALFONSO P., HAMID S.A., ANTICOI H., GARCIA-VALLES M., OLIVA J., TOMASA O., LOPEZ-MORO F.J., BASCOMPTA M., LLORENS T., CASTRO D., POLONIO F.G. 2020 - Liberation Characteristics of Ta-Sn Ores from Penouta, NW Spain. Minerals, 10 (6): 509.

BGS, 2011 - Mineral profil, Niobum-Tantalum. British Geological Survey, London.

BGS, 2015 - Risk List 2015. An Update to the Risk Index for Elements or Element Groups that Are of Economic Value. British Geol. Survey, London.

BLEISCHWITZ R., DITTRICH M., PIERDICCA CH. 2012 - Coltan from Central Africa, international trade and implications for any certification. Res. Policy, 37: 19-29.

BOLEWSKI A. (red.) 1994 - Encyklopedia surowców mineralnych Ś-Ź. Wyd. CPPGSMiE PAN, Kraków.

CALLAGHAN R.M. 2021 - Tantalum. [W:] USGS Mineral Commodity Summaries. USGS Publ., Washington: 164-165.

CUNNINGHAM L.D. 2001 - Tantalum. [W:] USGS Mineral Commodity Summaries. USGS Publ., Washington: 164-165.

DERA, 2018 - Rohstoffrisikobewertung - Tantal. Deutsche Rohstoffagentur, Berlin.

EC, 2017 - Tantalum. [W:] Study on the review of the list of Critical Raw Materials. Executive summary. European Commission, Brussels: 470-485 EC, 2020 - Tantalum. [W:] Study on the EU's list of Critical Raw Materials (2020). Critical Raw Materials Factsheets (Final). European Commission, Brussels: 735-752.

FAN H.R.,YANG K-F., HU F-F., LIU S., WANG K-Y. 2016 - The giant Bayan Obo REE-Nb-Fe deposit, China: controversy and ore genesis. Geoscience Frontiers, 7: 335-344.

GONZÁLEZ T.L., POLONIO F.G., LÓPEZ MORO F., FERNÁNDEZ A. CONTRERAS J., BENIT M.C. 2017 - Tin-tantalum-niobium mineralization in the Penouta deposit (NW Spain): Textural features and mineral chemistry to unravel the genesis and evolution of cassiterite and columbite group minerals in a peraluminous system. Ore Geol. Rev., 81: 79-90. https://europeanlithium.com/

https://www.metalary.com/tantalum-price/

https://www.usgs.gov/

MAGYAR M.J. 2006 - Tantalum. [W:] USGS Mineral Commodity Summaries. USGS Publ., Washington: 168-169.
MELCHER F., GRAUPNER T., HENJES-KUNST F. OBERTHÜR T., SITNIKOVA M., GÄBLER E., GERDES A., BRÄTZ H., DAVIS D., DEWAELE S. 2008 - Analytical Fingerprint of Columbite-Tantalite (Coltan). Mineralisation in Pegmatites - Focus on Africa. Ninth International Congress for Applied Mineralogy, 8-10 September 2008, Brisbane.

ORRIS G.J., GRAUCH R. I. 2002 - Rare Earth Element mines, deposits, and occurrences. Open-File Report 02-189, USGS Publ., Washington.

PADILLA A.J. 2020 - Tantalum. [W:] USGS Mineral Commodity Summaries. USGS Publ., Washington: 164-165.

PAPP J.F. 2011 - Tantalum. [W:] USGS Mineral Commodity Summaries. USGS Publ., Washington: 162-163.

PAPP J.F. 2016 - Tantalum. [W:] USGS Mineral Commodity Summaries. USGS Publ., Washington: 166-167.

PAULO A., STRZELSKA-SMAKOWSKA B. 1993 - Tantal. [W:] Paulo A. (red.), Materiały do ćwiczeń z nauki o złożach i geologii gospodarczej, część II: Rudy metali, t. I. Wyd. AGH, Kraków: 210-220.

POLYAK D.E. 2018 - Tantalum. [W:] USGS Mineral Commodity Summaries. USGS Publ., Washington: 164-165.

ROSKILL 2020 - Tantalum. Outlook to $2030,16^{\text {th }}$ Edition, London; Www.roskill.com

RUDNICK R.L., SALLY G. 2003 - Composition of the continental crust. Treatise Geochem., 3: 1-64.

SCHULZ K.J., PIATAK N.M., PAPP J.F. 2017 - Niobum and Tantalum. [W:] Schulz K.J., DeYoung J.H. Jr, Seal II R.R., Bradley D.C. (red.), Critical Mineral Resources of the United States - Economic and Environmental Geology and Prospects for Future Supply, USGS, Reston: Chapter M.

SIMANDL G.J., BURT R.O., TRUEMAN D.L., PARADIS S. 2018 Economic Geology Models 2, Tantalum and Niobium: Deposits, Resources, Exploration Methods and Market - A Primer for Geoscientists, Geosciences, Canada, 45: 85-96.

SKRZYPEK S.J. 2012 - Cyrkon, hafn, niob, wanad i tantal oraz ich stopy. [W:] Skrzypek S.J., Przybyłowicz K. (red.), Inżynieria metali i ich stopów. Wyd. AGH, Kraków: 487-506.

STRATTON P. 2013 - Outlook for the global tantalum market. $2^{\text {nd }}$ International Tin \& Tantalum Seminar, $11^{\text {th }}$ December 2013, New York.

SZLUGAJ J., SMAKOWSKI T. 2015 - Tantal. [W:] Smakowski T., Galos K., Lewicka E. (red.), Bilans Gospodarki Surowcami Mineralnymi Polski i Świata. Państw. Inst. Geol.-PIB: 955-960.

TIC, 2018 - Bulletin No. 172, 174. Tantalum-Niobium International Study Center, Brussels.

TIC, 2019 - Bulletin No. 176. Tantalum-Niobium International Study Center, Brussels.

TIC, 2020 - Bulletin No. 181. Tantalum-Niobium International Study Center, Brussels.

TIC, 2021 - Bulletin No. 184. Tantalum-Niobium International Study Center, Brussels.

USGS, 2013 - Metal Prices in the United States through 2010. Scientific Investigations Report 2012-5188, USGS Publ., Washington.

WOŁKOWICZ S. 2013 - 24. Konferencja Afrykańskiego Towarzystwa Geologicznego Addis Abeba, Etiopia, 6-14.01.2013: międzynarodowa pomoc dla Afryki czy neokolonializm naukowy? Prz. Geol., 61 (5): 290-293.

Praca wpłynęła do redakcji 19.02.2021 r.

Akceptowano do druku 23.03.2021 r. 